\author{
Izabella Zatorska \\ Instytut Romanistyki \\ Wydział Neofilologii \\ Uniwersytet Warszawski \\ e-mail: i.m.zatorska@uw.edu.pl \\ ORCID: 0000-0003-2048-4033
}

\title{
Przesławny los sekretnej poezji. Jean Paulhan - piewca hainteny merina
}

W 1896 roku Madagaskar stał się kolonią francuską. Dominacja wojskowa, za sprawą generała Gallieniego ${ }^{1}$, i polityczna, po abdykacji ostatniej królowej Ranavalony III (1883-1897), miały zostać wsparte przez kolonizację kulturową: pierwszym frontem było szkolnictwo, podobnie jak to miało miejsce w innych koloniach, do których dydaktyków ("laickich misjonarzy") rekrutowano we Francji spośród absolwentów tzw. Szkoły Jules-Ferry'ego, czyli szkoły wyższej kształcącej nauczycieli francuskiego w koloniach (école normale de l'enseignement colonial) ${ }^{2}$. Wyjątkiem okazał się Madagaskar: nowy (od 1905 roku) gubernator, Victor Augagneur, ponaglał, chętni mogli liczyć

\footnotetext{
1 Joseph Simone Gallieni (1849-1916), ledwie powrócił z 4-letniej misji do Tonkinu, został wysłany na Madagaskar, gdzie trwało powstanie menalamba, czyli czerwonych koszul, arystokracji niepogodzonej z upadkiem monarchii i feudalnej struktury władzy. Pozostał na wyspie jako gubernator do 1905 r. Jego korespondencję z 1. 1896-1905 wydano w 1928 r. [Société d'Éditions géographiques, maritimes et coloniales, w sieci: https://www.bibliothequemalgache. com/pdf/BME23.pdf, dostęp 14.07.2019]. Swój cel generał streszcza w trzech punktach: „przywrócić pokój; uczynić wyspę kulturowo francuską, i dać jak najszersze oparcie francuskiej kolonizacji” („,ramener la paix; franciser l'île et donner le plus grand appui possible à la colonisation française") [tamże, s. 16].

2 G. Vigner, L'École Jules-Ferry, école normale de l'enseignement colonial: une formation pour apprendre à enseigner dans les colonies (1902-1912), „Documents pour servir à l'histoire du français langue étrangère ou seconde" 2015, nr 5: (Se) former pour enseigner le français à ceux qui ne le parlent pas nativement, s. 57-82, https://journals.openedition.org/dhfles/4273 [dostęp 12.07.2019].
} 
na pracę w liceum (dla dzieci francuskich administratorów) nawet bez dodatkowego egzaminu i dyplomu ${ }^{3}$.

Badacz twórczości Paulhana może spytać, skąd - od dawna wyrywający się za morza (najchętniej ku Chinom, których języka zaczął się uczyć ledwie skończył lat 16) - Jean Paulhan miał tyle czasu i uwagi dla przedmiotu studiów, który upodobał sobie przez dwa lata spędzone na Czerwonej Wyspie, a który miał naznaczyć całe jego twórcze życie: w stolicy wyspy Tananarywie, podróżując po centralnym płaskowyżu, zamieszkałym przez ludność merina pochodzenia melanezyjskiego, osiadłą tam zapewne ok. roku tysięcznego ${ }^{4}$. Zapał nauczyciela francuskiego i filozofii ostudziło otoczenie: obojętność wyższych urzędników, priorytety ideologiczne - nowo przybyli nauczyciele-masoni burzą porządek zajęć z powodu zniżki godzin: w końcu już tylko on i jego kolega Cap „n.p.f.m.” („,n'est pas franc-maçon”), jak pisze Jeanne Paulhan do matki 9 kwietnia 1909 roku ${ }^{5}$. Na szczęście odkrył pasję swego życia, zagadkowy gatunek literacki, czyli hainteny [hejnteń] - „słowa mądrości". Formą zbliżone do malajskiego pantoum, z racji zwięzłości przyrównywane do japońskich haiku, zafascynowały go tak dalece, że - prócz zbiorów sporządzanych podczas wiejskich wieczernic - w swej bibliotece posiadał allografy sięgające połowy XIX wieku. Zawierała ona również korespondencje i raporty władców (głównie władczyń) Wyspy i ich otoczenia ${ }^{6}$, tudzież francuskich konsulów, oraz kroniki, bajki i przysłowia, słowniki francusko-malgaskie i vice versa, sporządzone przez misjonarzy, powieści (jak Décivilisé, czyli „Rozcywilizowany” z 1923 roku Charles'a Renela, kuratora szkolnego za czasów Paulhana) czy rozprawy, jak ta Jacques'a Aubera o „paranteli semantycznej między chińskim i malgaskim”, dedykowana

3 B. Baillaud, Préface - Ce qu'une communauté veut dire ou la Fuite en Émyrne, w: J. Paulhan, Les Hain-teny merina: poésies populaires malgaches recueillies et traduites par, Paris 2007, s. VII. Trwała wówczas rywalizacja między szkołą świecką i republikańską a szkołami misjonarzy obu głównych wyznań katolickich.

4 To właśnie oznacza ich nazwa, etnonim merina [emyrne]: „,ci z wyżyn” [F. Léry, Madagascar, les sortilèges de l'île Rouge, Paris 2001, s. 44]. Pochodzenie Malgaszy pozostaje zagadką, acz hipoteza spotkania na Czerwonej Wyspie mieszkańców Indonezji z afrykańskimi plemionami Bantou ma najwięcej zwolenników. Zob. J.-L. Joubert, Chronologie de Madagascar, w: Littératures de l'océan Indien, Paris 1991, s. 15.

5 J. Paulhan, w: Cahiers Jean Paulhan - 2. Jean Paulhan et Madagascar 1908-1910, Paris 1982, s. 35 i 43 , indeks listów s. 87-88.

6 W XIX w., spośród siedmiu osób panujących, tylko dwie noszą spodnie (nie jest to malgaski strój tradycyjny, a pierwszy w tej serii władca, zjednoczyciel wyspy Andrianampoinimerina (1787-1810) przedstawiany jest okryty krótką lambą, udrapowanym kawałkiem jedwabiu. Od 1863 trzy królowe zmieniają się na tronie, kolejno poślubiając „etatowego" premiera, Rainolaiarivony. Trzy z czterech władczyń noszą imię Ranavalona. 
Paulhanowi $i^{7}$ Jest też wydany $w$ Antananarywie ${ }^{8}$ w roku śmierci Paulhana dwujęzyczny zbiór hainteny pod redakcją uczennicy René Etiemble’a, zasłużonej badaczki malgaskich przysłów, Bakoly Domenichini-Ramiaramanana ${ }^{9}$.

Trzy lata po powrocie z wyspy Paulhan publikuje w Paryżu zbiór około stu sześćdziesięciu Hain-tenys merina, poésies populaires malgaches [Hainteny ${ }^{10}$ merina, ludowa poezja malgaska]. W 1938 roku zbiór ten doczekał się reedycji u Gallimarda, ale już mocno uszczuplony ${ }^{11}$. Paradoksalnie ten, kto przybył kolonizować kulturowo malgaskich nauczycieli ${ }^{12}$, sam stał się uczniem: pilnie czynił postępy w malgaskim, by samodzielnie porozumiewać się z miejscowymi informatorami, słuchać i notować hainteny u źródła, wędrując po wsiach płaskowyżu; zebrał w sumie około ośmiuset utworów. Jak wygląda dzieło jego życia, jaki wpływ wywarło na malgaskich i na europejskich, a zwłaszcza na francuskich odbiorców? Co przesądziło o jego krótkotrwałej popularności?

Pierwsze spisy hainteny powstały za panowania Ravanalony I (1828-1861), w 1832 roku, za sprawą cudzoziemców, których władczyni wkrótce wyrzuciła z wyspy. Wcześniej, w 1823 roku, jej małżonek, król Radama I, wprowadził rękami misjonarzy angielskich, tłumaczy Biblii protestanckiej, łacinę, która zastąpiła święty alfabet sorabe, pismo arabskie używane od wieków do transkrypcji tajnych przekazów władców. Nawet jeśli gremialny powrót cudzoziemców na wyspę nastąpił dopiero po śmierci władczyni wspierającej tradycję religijną i kulturową, ciążenie ku cywilizacji zachodniej nabrało już wtedy swojej dynamiki.

We wprowadzeniu do zbioru z 1913 roku Paulhan barwnie opowiada, w jakich warunkach odkrywał hainteny:

7 J. Auber, Parenté sémantique du chinois et du malgache, Tananarive 1957.

8 Po odzyskaniu przez Madagaskar niepodległości w 1960 r. przedrostek $A n$ - powrócił do nazwy stolicy; sami mieszkańcy zdrobniale mówią o niej Tana.

9 B. Domenichini-Ramiaramanana, Hainteny d'autrefois, Poèmes traditionnels malgaches recueillis au début du règne de Ranavalona 1 (1828-1861), Haintenin'ny fahiny, voaangona tamin'ny voalohandohan'ny nanjakand Ranavalona I, Tananarive, 1968 [?]. Dotyczy hainteny zebranych w roku 1832.

10 Ortografia słowa uległa zmianie od czasu Paulhana; wzorem wydawców jego pism, starą wersję, z łącznikiem, zachowam dla cytatów z epoki.

11 Wydanie Gallimarda z 1938 r., pozbawione komentarza, zawiera zaledwie 127 hainteny. Pierwszy wydawca, Geuthner, jeszcze w 1964 r. dysponował prawami do książki - do niego zwrócili się wydawcy dzieł wszystkich (CEuvres complètes) w połowie lat 60. - „Cercle du Livre Précieux". Ostatnia reedycja, w roku 2007 pod szyldem odnowionej S.N. LIBRAIRIE ORIENTALISTE PAUL GEUTHNER S.A. - reprint pierwszej, niemal sto lat później - daje pierwotny zestaw.

12 Paulhan wykłada na kursach dla miejscowych nauczycieli. Uczniowie liceum to Francuzi lub Kreole, przybyli z wyspy Reunion, francuskiej kolonii od XVII w. 
Życie Merina, gdy nie zaznało jeszcze wpływów europejskich, otoczone jest licznymi fady [zakazami religijnymi, tabu - dop. I.Z.]. Jedna jedyna izba, w domu zbudowanym z surowych cegieł lub drewna, mieści palenisko, łoże, mur u stóp którego zanosi się modły do przodków, nową matę, na której spoczną goście, ażurową klatkę z kurami i centralny słup, do którego jest uwiązane cielę. Potrzeba nieustannej troski, aby sens i wartość każdego miejsca były uszanowane. Droga, jaką przebędzie obcy, gdy po raz pierwszy wejdzie do tego domu, droga dziecka, które mu towarzyszy albo droga kury powracającej do klatki - każda $\mathrm{z}$ tych dróg jest poddana ścisłym regułom. Nawet promienie słońca nie mogą przypadkowo zaglądać do chat jednakowo zorientowanych; jest pora, gdy „ukazują się na progu” [poranek - dop. I.Z.], jest inna, gdy „dosięgają centralnego słupa” [południe], i jeszcze inna, dużo później, gdy „wylot/obręb garnków okrywa się cieniem" [podwieczerz]. Przez cały dzień mieszkaniec Merina zachowuje tę samą dbałość i ostrożność. Nie uchodziłoby, jest nawet fady w niektórych rodzinach hova czy andriana [stan średni i arystokracja Merina - dop. I.Z.], by recytować wiersze w ciągu dnia, a nawet, by wtedy śpiewać. Wieczorne czuwanie [la veillée du soir], po posiłku, jest zarezerwowane dla legend, bajek i hainteny.

Oto scena, jakiej wielokrotnie byłem świadkiem: po skończonym posiłku dzieci zabierają matę, na której się jadło i kładą czystą - wprowadza się kilku mieszkańców wioski, którzy oczekiwali na podwórzu. Siadają na macie, w pobliżu gospodarzy, i jeden z gości zabiera głos, recytując kilka wersów. Mówi je mocno wybijając rytm i to z taką energią, że zdaje się składać skargę lub czegoś domagać. Jeden z mieszkańców - ojciec lub syn, niekiedy jedna z żon - odpowiada mu tym samym tonem, to gwałtownym, to ironicznym. Gość odpiera atak. Dyskusja trwa. Słuchacze, to ten to ów, dołączają, rzucając po kilka krótkich rytmicznych słów, które zdają się zmierzać do tego, by dyskusja powróciła na właściwy teren. Repliki obu adwersarzy stają się coraz dłuższe, coraz mocniej skandowane - każdy ma swoich zwolenników, którzy go zachęcają okrzykami i śmiechem. Krzyczą do siebie różne odpowiedzi: jeden $z$ nich znajduje raptem najwyraźniej właściwe słowa, bo drugi waha się, nie odpowiada, czyli uznaje się za pokonanego, a zgromadzeni cisną się wokół jego przeciwnika.

Obcy wtedy wychodzą, a starzy opowiadają legendy o przodkach, które układają mieszkańców do snu ${ }^{13}$.

Społeczną rolę hainteny ilustruje następnie kilka anegdot z życia Merina, poczynając od historii dekarza, który wieczorem przyszedł upomnieć się o swoją zapłatę (żądał ekwiwalentu 60 centymów miast 30) i - stając do walki na hainteny - wygrał i otrzymał zapłatę, jakiej żądał [HTM, s. 9-10].

Recytacja hainteny niewiele dotąd interesowała Europejczyków, którzy są wielkimi ignorantami, jeśli idzie o rytuały i dogmaty religii malgaskiej, zauważa Paulhan. Nic dziwnego, sami Merina, świeżo ochrzczeni, niechęt-

13 J. Paulhan, Introduction - Observation des hain-teny, w: Les Hain-teny merina, Paris [1913] 2007, s. 7-9. Wszystkie cytaty z tego wydania są w moim przekładzie, sygnowane w tekście skrótem HTM i numerem strony. 
nie przyznawali się misjonarzom do niedawnych praktyk i starali się o nich zapomnieć. Hainteny, jako poezja lekka (swawolna obyczajowo), była przez konwertytów uważana za "diabelską inspirację" (czy to aby nie misjonarze im podpowiadali ten epitet?). Efekt? Ewolucja malgaskiego, która przyspieszyła w 2. połowie XIX wieku, odbyła się poza językiem ludowej poezji, a nawet poniekąd przeciw niemu. Od 50 lat - notuje Paulhan - europejscy profesorowie uczą Merina, wykuwa się malgaski katolicki lub protestancki [HTM, s. 14, przyp. 1]. Dlatego język hainteny wydaje się „ciemny", niejasny - to ,język martwy dziś dla wykształconego Merina, który uczył się w szkołach europejskich, nawet jeśli nie jest chrześcijaninem" [HTM, s. 13-14]. Wypada inaczej ocenić, $\mathrm{w}$ tej perspektywie, wyrzucenie $\mathrm{z}$ jezuickiego liceum (za niesubordynację?) Jean-Josepha Rabearivelo (1903-1937), odnowiciela malgaskiej literatury: ojca poezji oryginalnej, choć francuskojęzycznej, odnowiciela tej $w$ języku macierzystym.

Tymczasem, jak zauważa Paulhan, jedynie w wioskach, które jeszcze nie przyjęły chrztu, recytacje hainteny są powszechne; w pozostałych tylko andevo (prywatni niewolnicy) jeszcze uprawiają tę sztukę, jako jedyni niechrześcijanie. Członkowie dawnego rządu, pierwsi przyjmujący wpływy europejskie, zapewniali Paulhana, że $w$ ich rodzinach, jak pamiętają, rodzice wieczorem zbierali się, by recytować hainteny - była to forma dyskusji i pouczeń [HTM, s. 15].

To jednak właśnie niemal po dziś dzień stanowi przedmiot sporu: czy, jak chciał Rabearivelo, hainteny powstały zrazu wśród hova, malgaskiej „klasy średniej" ${ }^{14}$, do której sam należał? Czy też, jak przypuszczała Nivoelisoa Galibert Ratsiorimihamina (1953-2011), badaczka i pisarka rodem z andriana, korzenie hainteny są wielorakie: i arystokratyczne, i ludowe; poezja ta obecna jest wśród wielu szczepów wyspy, zmienia się tylko nazwa. Istotnie, Noro Rakotobe-D’Alberto przypomina słowo saim-bola z dialektu ludu Sakalava (mieszkańcy zachodnich połaci wyspy, odwieczni rywale Merina), które znaczy dokładnie to samo, co hainteny $\mathrm{w}$ dialekcie merina ${ }^{15}$. Swoje miejsce w saim-bola znajduje filan'ampela, co oznacza dosłownie „sposób na znalezienie żony" ${ }^{16}$. Bo też idzie o wszelką poezję, „której celem jest otrzymanie ko-

\footnotetext{
14 Sam Paulhan tak ich przedstawia: „ils étaient la classe moyenne” [HTM, s. 1].

15 „En fait, les filan'ampela sont des saim-bola, c'est-à-dire des paroles spirituelles, des mots d'esprit, en quelque sorte. Le mot saim-bola du dialecte sakalava correspond à celui de hain-teny du dialecte merina" [N. Rakotobe-D'Alberto, L'univers culturel malgache dans les Chansons madécasses d'Évariste Parny, w: Lumières et océan Indien, dir. Ch. Meure, G. Armand, Paris 2017, s. 67-84].

16 „Filan'ampela signifie littéralement «moyen de chercher femme»", chodzi o „propos galants" (zalotne słowa) [N. Rakotobe-D’Alberto, s. 75].
} 
biecej przychylności"17. Aczkolwiek Paulhan odnotowuje jakościową różnicę między hainteny a ich homologami, przede wszystkim zaś między językiem Merina a językami ludów z innych części wyspy: „Ich język jest także językiem innych plemion na wyspie, różni go jedynie stopień złożoności i większe bogactwo pojęć abstrakcyjnych” („Leur langue est aussi celle des autres tribus de l'île, plus complexe seulement et plus riche en idées abstraites") $[\text { HTM, s. } 1]^{18}$. Ale kolejne nazwy, jakie Paulhan przypisuje hainteny, dotyczą raczej gatunków wypowiedzi, które składają się na ich „wiedzę słów” („,science des paroles") [HTM, s. 2]: przykłady (fr. exemples, malg. ohatra), słowa-przykłady czyli przysłowia (malg. ohabolana), zagadki (fr. devinettes, malg. ankamantatra), pytania retoryczne (malg. fampanononana: "questions énigmatiques qui appellent une réponse"). Jakie miejsce owe "cegiełki" zajmują w poszczególnym hainteny, jakie funkcje i sensy się z tym wiążą, to analizuje Paulhan w dalszej części. Zaczyna od drobiazgowej analizy siedmiu hainteny (transkrypcja-przekład-eksplikacja, oparta na wyjaśnieniach Malgaszy), zestawia je ze sobą, nawiązując do obyczajów Merina, do ich stylu myślenia. Jak sam wspomina, jego stosunek do malgaskich wierszy zmieniał się:

Najpierw poznałem je z książek, później usłyszałem, jak je wygłaszano; w końcu sam zacząłem je wymyślać i wygłaszać ${ }^{19}$. Tym sposobem stopniowo zmieniały się moje zapatrywania na nie, niekiedy nowe były zaprzeczeniem poprzednich. Opiszę moje doświadczenia. / Opiszę je bez pomijania niezręczności ani błędów ${ }^{20}$.

17 Hébert zauważa, że w dialekcie sakalava to wyrażenie "désigne toute poésie, bouts rimés ou non, ayant pour but d'obtenir les faveurs d'une femme" [J.-C Hébert, Filan' Ampela", ou propos galants des Sakalava, w: "Journal de la Société des Africanistes", t. 34, fasc. 2, 1964, s. 227].

18 Nivoelisoa Galibert wymienia homologów hainteny - gatunki znane wśród innych malgaskich ludów: „si les genres narratifs ont une appellation unique pour toute l'île (angano [bajka, powiastka, fr. conte]), les genres prosodiques sont nommés suivant leur région d'origine: le hainteny (merina), saimbola (sakalava) ou fampariahitse (betsileo) voient leurs dérivés chantés dans le osiky tsimihety (subdivisé en jijy - coq-à-l'âne - et sôva - descriptions), dans le beko antandroy qui loue les clans et les coutumes du groupe, le rija (betsileo) qui chante l'amour ou les exploits historiques..., autant d'œuvres d'un art essentiellement verbal qui habille les cérémonies rituelles aussi bien que le quotidien" [N. Galibert, Palimpseste et itération dans l'écrit littéraire malgache de 1926 à 1972, brudnopis pliku autorskiego].

19 W Introduction z wyd. z 1913 r. Paulhan pisze, że dopiero wtedy, gdy opanował pamięciowo sporą liczbę hainteny był w stanie włączać się do dysputy: "Je dus apprendre une quantité suffisante de hainteny pour pouvoir soutenir une discussion" [HTM, s. 15].

${ }^{20}$ J. Paulhan, Les hain-teny, poésie de dispute - Introduction, w: J. Paulhan, Les Hain-tenys, Paris 1938 [druk foto-offsetowy z 1960 r.], s. 7-8. Cytaty z wydania międzywojennego w tekście oznaczone skrótem HT i numerem strony. 
Przyjęcie książki w roku 1913 wzbudziło zainteresowanie tak w kręgach literackich, jak i etnograficznych; w reedycji z 1938 roku Paulhan przywołuje raczej artykuły antropologów i psychologów niż literackie analizy ${ }^{21}$. Ciekawe jest zestawienie różnic między wydaniami z 1913 i z 1938 roku. Były ilościowe i jakościowe: te pierwsze, bo ze 163 hainteny (z czego 7 szczegółowo zanalizowanych i omówionych w pierwszej części, dwa podane w kilkunastu wariantach) zostało po ćwierć wieku 127; różnice jakościowe dotyczą przede wszystkim braku malgaskiego oryginału w międzywojniu: adresatem jest szeroka publiczność literacka. Nowa przedmowa - krótsza niż wieloetapowa prezentacja z 1913 roku - kładzie akcent na dwa aspekty: poezję miłosnego sporu, poezję "ciemną", zagadkową. Dlatego w zredukowanych do minimum przypisach tłumacz zawsze pozostawia informację: Kto mówi? Kobieta czy mężczyzna? Kto komu odpowiada?

W obu wydaniach, w czym - jak i w przekładach - Paulhan jest nowatorem, hainteny są typograficznie zaprezentowane jako wiersze, inaczej niż u misjonarzy, np. pastora Larsa Dahle'a w 1877 czy eks-pastora, eks-dowódcy malgaskiej armii Rainandriamampandry (1836-1896), autora Historii Madagaskaru, rozstrzelanego z rozkazu generała Gallieni w roku ukończenia monografii o hainteny. Obaj zapisywali je na ogół jak prozę, tyle że poetycko stylizowaną. Dahle - jak przypomina Nivoelisoa Galibert - dostrzegał formalne podobieństwo hainteny do poezji hebrajskiej, do ludowego norweskiego przysłowia (ordsprog) i do arystokratycznego stev - wiersza z popisów oratorskich, związanych z naprzemiennymi śpiewami w Skandynawii ${ }^{22}$.

Rzecz zabawna, prezentując zasadniczy korpus, stale podzielony według ośmiu kryteriów tematycznych - które uznaje za niezbyt trafne, ale ułatwiające orientację europejskim czytelnikom - nazwę jednego i tylko jednego z tych kręgów badacz zmienia: w 1913 roku pierwszy podzbiór zawiera wiersze "na temat wyznania miłości” (déclaration d'amour) [HTM, s. 75], w 1938 roku pierwszy temat brzmi „pożądanie” (désir) [HT, s. 69], stanowiąc ślad większej swobody obyczajów w Europie po I wojnie światowej. Pozo-

\footnotetext{
21 Przywołuje m.in. studia sinologa M. Graneta i psychologa M. Jousse'a [HT, s. 67].

22 "Poème de joute oratoire lié aux chants alternés en Scandinavie”; monografia Graneta o świątecznych piosenkach w dawnych Chinach, przywołana przez Paulhana w nocie do wydania z 1938 r., wskazuje na kolejne pokrewieństwo, azjatyckie, dodaje N. Galibert [tamże]. Ciekawą próbkę przynosi Jana Potockiego Podróż na Kaukaz; pisarz cytuje kilka strof z „trubadura tatarskiego [tj. kałmuckiego, który] przygrywa [sobie] na dwustrunnej gitarze [...]: «Zostawiłem w ogrodzie kwiat, którego nikt nie dostrzegł; wyruszam w podróż i widzę po drodze wąwóz o urwistych brzegach». "Mój krogulec i koń nie poznają już mego głosu; chciałem schwytać feniksa, ale w sieci znalazłem same wrony»" [J. Potocki, Podróże, zebrał i oprac. L. Kukulski, Warszawa 1959, s. 320-321].
} 
stałe tematy to zgoda (consentement), odmowa (refus), wahanie i rywalizacja (hésitation et rivales), rozłąka i opuszczenie (séparation et abandon), żale i wymówki (regrets et reproches), duma (orgueil) i kpina (raillerie) ${ }^{23}$.

Oba wstępy mają także odmienny cel ogólny: o ile w 1938 roku nieprzewidywalność i zagadkowość hainteny bierze górę, jako wyróżnik poezji w ogóle, o tyle w 1913 roku Paulhan starał się dowieść, że "słowa mądrości" czy „miłosnego sporu” w ogóle są poezją. W analitycznym komentarzu do wydania siedmiu wierszy, tworzących serię zaprezentowaną na jednym z wieczorów, badacz zastanawia się, jak to było możliwe, że pierwsi zbieracze hainteny - misjonarze protestanccy czy uformowani przez nich Malgasze, jak Rainandriamampandry - zapisywali je jak prozę? Wszyscy oni przyjęli już europejskie (dziewiętnastowieczne) kryteria rozpoznania poezji. Nie widzieli $\mathrm{w}$ tych prostych, bezrymowych zdaniach niczego nadzwyczajnego: nie tak wyglądały pieśni protestanckie czy poezje drukowane w malgaskiej prasie sponsorowanej przez misjonarzy. Sam Paulhan zapytał o to pewnego Hova ze stolicy: „Jak może pan przypuszczać, że hainteny to poezja - odparł zapytany. Nie ma w nich rymów, i znają je wszyscy niewykształceni Malgasze" („Comment pouvez-vous penser que les hain-teny sont des vers [...] Ils n'ont pas de rimes, et tous les Malgaches ignorants les savent”) [HTM, s. 46]. Od tak myślących Merina Paulhan zebrał większość spisanych przez siebie hainteny [tamże].

W 1913 roku Paulhan stara się więc przekonać czytelników (krytyków literackich i antrolopologów kultury), że hainteny są poezją. Logika i precyzja (użycia) na to wskazują: bo w transkrypcji hainteny jako prozy zaniedbuje się zasady tejże transkrypcji przyjęte dla literatury ustnej (rytm i pauzy?); co więcej, sami Malgasze przypisują hainteny podobną funkcję społeczną, jak Francuzi wierszom (recytacja po pracy, wymiana doświadczeń ujętych w głębsze przemyślenia [HTM, s. 42]). Ponadto hainteny mają te same słowa, co piosenki, niewątpliwie poezją będące (chyba że się to ostatnie

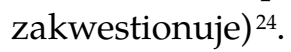

Problem jest z samą definicją wiersza, przyznaje Paulhan; bo co łączy wiersz Wergilego, La Fontaine'a i Paula Claudela z popularną piosenką? Badacz podaje swoją definicję poezji, odwołując się do "znaczeń rzeczywistych" (sens réels), a nie "teoretycznych" (théoriques), przypisanych jej przez "grama-

23 Odpowiada im w wydaniach z 1913 i 1938 r. różna liczba przykładów: 18 i 17, 15 i 13, 18 i 18, 17 i 16, 17 i 17, 23 i 18, 18 i 16, 16 i 12, w sumie 142 i 127, dodatkowo w wydaniu Geuthnera 7 hainteny z jednej serii na wstępie, oraz - w Appendice I i II - 12 i 2 wiersze tworzące serie wariacyjne, co daje w sumie 163 przykłady.

24 Przykłady zbieżności przysłów z hainteny i piosenek [HTM, s. 44-45]. 
tyków”: „język harmonijny, wyszukany, który nie przypomina języka potocznego i który go przerasta. Wers jest dla tego języka tym, czym słowo lub grupa słów są dla języka potocznego” („Langue harmonieuse, recherchée, qui est autre chose que le langage commun et qui lui est supérieure. Le vers est à cette langue ce que le mot, ou le groupe de mots, est à la langue commune") [HTM, s. 47]. Zestawia intuicję francuskiego wieśniaka z odczuciem każdego Merina, dla którego poezja to właśnie ,język, który jest badaniem i nauką" („,une étude et une science"), czyli język hainteny, piosenek i przysłów. W kwestii rymu Paulhan cytuje niejakiego „brata Rafaela” 25. „Rym, dodaje, zważywszy na łagodne i melodyjne brzmienie malgaskiego, jest niepotrzebny ich wierszom” („La rime, ajoute-t-il, étant donné la sonorité douce et musicale de la langue, est inutile au vers malgache") [HTM, s. 48] ${ }^{26}$. W wersji malgaskiej brak nawet interpunkcji, oprócz '?' i '!', zgodnie z intonacją recytujących: jedynie pauza tej samej długości po każdym wersie[!] jest uwzględniana - pomaga ustalić wersyfikację.

Bez stałej cezury ani rymu, hainteny oparte są za to na licznych asonansach - początkowych, środkowych i końcowych („,initiales, médiales, ou finales"). Mogą być wzbogacone o grę słów, np. gatunku rośliny i czasownika [HTM, s. 49: sadzenie figowca i palma Christi a przybycie lub powrót ukochanej]. Zdarzają się powtórzenia znaczące: paralelizmy, symetrie, które mogą objąć nawet 12 wersów. Dzięki tej grze symetrii, czasem odwróconej, Paulhan wierzy, że dotyka twardego jądra tej poezji, tj. kilkuset modeli, "słów-przykładów", czyli wzorów, których kolejne setki wariantów dają to, co nazywamy hainteny [HTM, s. 52-53]. W poszczególnym wierszu punktem wyjścia jest przysłowie, rozwijane w warianty, obrazy, które odnawiają jego sens [HTM, s. 54] ${ }^{27}$.

Jak to możliwe, pyta dalej Paulhan, by gatunek tak frywolny był użyty w obronie poważnych interesów? Ale też jaką miłość, w jakiej sytuacji i w jaki sposób ukazują hainteny? To nie zmysłowa miłość orientalna z poezji arabskiej, ale intelektualna i rezonująca, która daje pretekst do sporu, a przynajmniej do dyskusji: agresywna czy upokorzona, pokorna czy pyszna, zawsze

\footnotetext{
25 „Biuletyn Akademii Malgaskiej” 1907 s. 51. Przyp. 3 u J. Palhana [HTM, s. 48].

${ }^{26}$ Jak podkreśla Nivoelisoa Galibert: „la véritable unité de ces poésies traditionnelles se situe dans la déclamation. De façon générale, le rythme ondulatoire provient du fait que les vers, chantés ou non, ne se comptent pas au nombre de syllabes, mais se mesurent à la force des accents" [N. Galibert, Palimpseste et itération dans l'écrit littéraire malgache de 1926 à 1972].

27 Nivoelisoa Galibert podkreślała znaczenie wrażeń słuchowych: „les métaphores et les métonymies propres à la poésie traditionnelle s'enrichissent à chaque édition des nouvelles harmoniques assignées par le récitant. Par sa seule intonation, ce dernier crée à côté du texte explicite un texte implicite à son gré" [tamże].
} 
jest to miłość, która jeszcze nie zdołała się narzucić, miłość wzgardzona. Jest skłócona, właśnie z powodu miłości. W tej kłótni odnajduje się pierwotna rywalizacja, będąca powodem zastosowania hainteny: „Dekarz, który upominał się o zbyt wygórowana zapłatę był skrzywdzoną dziewczyną, która porzuca swego przyjaciela, a pan domu, występując w roli owego przyjaciela, błagał ją, by wróciła” („Le couvreur de toits qui réclamait un salaire trop élevé fut la jeune fille maltraitée qui abandonne son ami, et le maître de la maison, devenu cet ami, la suppliait de revenir") [HTM, s. 59].

W 1938 roku Paulhan podkreśla kontrast i naprzemienność konstrukcji malgaskich „mądrych słów”: po „słowach jasnych” (przysłowiach) następują "słowa ciemne" (symbole, metafory), te właśnie, które naprowadzają na istotę poezji - $\mathrm{w}$ ogóle i $\mathrm{w}$ danym wierszu. Dziwi zatem, że $-\mathrm{w}$ tym samym wydaniu - mówi o zakończeniu zawierającym uniwersalną prawdę (powrót przysłowia - wiersz gnomiczny) albo stek niedorzeczności (,głupot"; tu: fatrasie). Początek stanowią często słowa zachęty - do ostrożności, oszczędności, wierności - oraz maksymy, sentencje, zalecenia grzeczności i uprzejmości, zwieńczone enigmatycznym, dziwacznym zdaniem, które nadaje nowy, metaforyczny charakter utartym znakom; niekiedy też samo zestawienie przysłów, paralelne, lub tworzone na ich wzór zdania, budują nastrój, kontrapunktowany tym bardziej zaskakującą pointą:
Blask księżyca w dole ${ }^{28}$.
Jasność we wsi.
Ten dym, na Zachodzie,
To nie dym, lecz kokieteria.
Ten ryż, który ktoś ubija, na Wschodzie,
To nie ryż, który ktoś ubija, ale miłosny kaprys.
Wybiorę się z wizytą? ${ }^{29}$ Mam [przecież] żonę.
Jeśli tu zostanę, będzie mi wstyd ${ }^{30}$ [HTM, s. 19].

Nivoelisoa Galibert widzi na ogół w pierwszych wersach „subtelną obserwację przyrody, która umieszcza zwierzęta i rośliny w roli jeśli nie głów-

\footnotetext{
${ }^{28}$ Fosa w oryginale: otaczająca wioski merina, by je chronić przed niespodziewanym atakiem (przyp. J. Paulhana).

${ }^{29}$ Sens pełny: czy przyjdę do ciebie? Wieczorną porą mężczyzna żonaty wyznaje innej kobiecie miłość: wszystko, odgłos ubijanego ryżu czy dym unoszący się znad chat mu o tym mówi (komentarz J. Paulhana).

30 Końcowy dylemat ma analogie w innych przysłowiach, np. ktoś mówi o rosnących przy drodze cytrynach: „Irai-je les prendre? Je ne suis pas leur maître. / Si je reste ici, je désirerai les manger” [HTM, s. 53]. Por. „Irai-je en visite ? J'ai une femme. / Si je reste ici, j'aurai honte” [HTM, s. 19].
} 
nego tematu, to przynajmniej elementu porównania" ${ }^{31}$. Powołuje się na rozprawę doktorską zaprzyjaźnionej z Jeanem Paulhanem Bakoly Domenichini-Ramiaramanana: tej, która przełożyła i opracowała pierwsze hainteny zebrane w 1832 roku. Wyprowadziła z tego materiału trzy wnioski dotyczące: 1) sugestywnych obrazów na usługach tematyki miłosnej, gdzie słowny popis (la joute verbale) często przybiera postać rozmowy kochanków (colloque amoureux); 2) zwięzłości, która jest także jednym z powodów polisemii i cechą elitarnej, proroczej wypowiedzi masimbava, tj. arystokraty wyznaczonego do funkcji rytualnych; 3) hermetyzmu, wynikłego ze znominalizowanego języka podległego kodom kulturowym, skomplikowanego przez użycie aluzji i efektów poetyckich ${ }^{32}$. Aby ukazać ich możliwości polisemiczne, czyli interpretacyjne, ta sama badaczka zestawia trzy różne wersje francuskiego przekładu tego samego "klasycznego" hainteny: dwie pochodzą od niej (I i III), jedna (II) od malgaskiego poety, tłumacza i naśladowcy hainteny, Flaviena Ranaivo (1914-1999). Podaję je poniżej w wersji francuskiej i polskiej. Wariant I, przekład Bakoly Domenichini-Ramiaramanana:

Le tonnerre gronde au loin dans l'Ankaratra

Les orchidées fleurissent au loin dans

l'Anjafy

Petit-d'oiseau-bleu se met à pleurer

Qui-ne-craint-le-juste retour-des-choses se

met à éclater de rire

Si c'est un juste retour de mort qu'il ne soit accompli

Mais si c'est un juste retour d'amour qu'il soit accompli
Grzmi w oddali w masywie Ankaratra Orchidee kwitną w dali na wyżynach Anjafy

Niebieski-ptaszek zaczyna płakać

Śmiało-czekający-na-sprawiedliwy-obrót-rzeczy wybucha śmiechem

Jeśli to sprawiedliwy obrót śmierci niech się nie dopełni

Lecz jeśli to słuszna wzajemność

w miłości niech się spełni

Ankaratra to góry na południe od Tananarywy, uznane tradycyjnie za siedzibę duchów, bogów i książąt; Anjafy - góry oddzielające od Merina ich zbuntowanych sąsiadów, Sihanaka ${ }^{33}$. Ostatni wers zawiera aluzję do rytuału famoizana (wyrzeczenie się), gdy w przeddzień nowego roku po raz ostatni opłakiwało się zmarłych $\mathrm{w}$ roku odchodzącym: ich wezwanie zdawało się

31 „Une fine observation de la nature qui fait figurer animaux et plantes sinon comme sujet principal du moins comme éléments de comparaison" [N. Galibert, Palimpseste et itération dans l'écrit littéraire malgache de 1926 à 1972].

32 B. Domenichini-Ramiaramanana, podaję za N. Galibert, Palimpseste et itération dans l'écrit littéraire malgache de 1926 à 1972.

33 Zestawienie i komentarz malgaskiej badaczki podaję za artykułem J.-L. Jouberta, Poésie et traduction à Madagascar, „Étiopiques”, , nr 34 i 35, revue socialiste de culture négro-africaine nouvelle série $3^{\mathrm{e}}$ et $4^{\mathrm{e}}$ trimestre de 1983, vol. 1, nr 3 et 4, http://ethiopiques.refer.sn/spip.php?article923 [dostęp 12.11.2018]. 
wybrzmiewać w uderzeniu samotnego gromu od strony gór Ankaratra; to był także czas, gdy rozłączeni małżonkowie mogli się spotkać na ostatnim miłosnym rendez-vous ${ }^{34}$. W I wersji imiona własne postaci brzmią dosłownie. Kolejne wersje przynoszą brzmienie literackie (II - Ranaivo) lub przenośne, o zastosowaniu potocznym (III):

\section{II - LE CHÂTIMENT}

Il tonne,

il tonne dans les monts d'Ankaratra

Et fleurissent,

fleurissent les orangers d'Anjafy.

Elle pleure,

elle pleure la-fille-de-l'oiseau

bleu,

et ricane,

ricane celui-qui-ne-craint-pas

le-châtiment-en-retour.

Si châtiment de mort, qu'il y soit sursis ;

si châtiment d'amour,

qu'il soit appliqué.

III - Que gronde l'orage au

Mont-des-Immortels

Au Pays-des-Enfants fleurit l'orchidée

Éclatent les pleurs de Jeune-Tourterelle

Éclatent les rires de Ne-craint-leretour

Ne soit pour le deuil aucun juste retour

Mais soit pour l'amour la justice accordée.
II - SĄD

Grzmi,

grzmi na szczytach Ankaratra

I kwitną,

Kwitną drzewa pomarańczowe

Na wyżynie Anjafy.

Płacze,

płacze córka-błękitnego-ptaka,

i śmieje się,

śmieje ten-który-nie-boi-się-wyroku-

-nieodwołalnego.

Jeśli to wyrok śmierci,

niech będzie w zawieszeniu;

jeśli wyrok miłości,

niech będzie wykonany.

III - Niech grzmi na Szczycie

Nieśmiertelnych

W Krainie Dziecięctwa kwitnie orchidea Wybucha płaczem Młoda Turkawka Wybucha śmiechem Nie-drżący-przed-powrotem

Żadnego powrotu niech nie będzie dla żałoby

Ale miłości niech oddadzą sprawiedliwość.

Każda wersja preferuje inne dominanty strukturalne: kontrast w pierwszej (płacz/śmiech, śmierć/miłość); lęk dziewczyny (legendarna ptasia córka, jak w kantacie-balecie z tekstem Rabearivelo) i odwaga bohatera dołączają $\mathrm{w}$ drugiej wersji do powyższych binomów, typowych dla malgaskiej topiki; ale już w trzeciej wersji pierwotny kontrast, ujęty w paralelizm (wybucha płaczem/wybucha śmiechem) zostaje przezwyciężony w końcowym dwuwierszu, głoszącym jednoznacznie triumf miłości. O ileż więcej jeszcze niuansów można z pewnością wydobyć dzięki stosownej dykcji i akcentom!

34 Tamże. 
Ranaivo dodał tytuł, tematyzując materię wiersza. Podobnie postąpił z wierszem Regrets [Żale/Tęsknoty/Wymówki], stylizowanym na hainteny: zamykał on w 1948 roku tom manifestu "murzyńskości” (négritude), opracowanego przez Leopolda Sedara Senghora, z przedmową Jean-Paul Sartre'a Orphée noir (Czarny Orfeusz), s. IX-XLIV ${ }^{35}$. Poniżej tekst Regrets i mój polski przekład:

Six routes

partent du pied de l'arbre-voyageur :

la première conduit au village-de-

l'oubli,

la seconde est un cul-de-sac,

la troisième n'est pas la bonne,

la quatrième a vu passer la chère-aimée mais n'a pas gardé la trace de ses pas, la cinquième

est pour celui-que-mord-le-regret, et la dernière...

je ne sais si praticable.

\section{Sześć dróg}

biegnie od stóp drzewa-podróżnika:

pierwsza prowadzi do osady-zapomnienia,

druga jest bez wyjścia,

trzecia nie jest dobra,

czwarta widziała, jak szła ukochana

ale ślad jej kroków się nie zachował,

piąta

jest dla tego-co-go-gryzie-żal,

a ta ostatnia...

nie wiem, czy da się nią przejść.

Stylizacja, jak w przypadku Pieśni z Madagaskaru Ewarysta Parny'ego (wydane w 1787), widoczna jest w odejściu od tradycyjnej parataksy, paralelizmów i symetrii składniowych i leksykalnych w stronę zróżnicowania, a nie prostej gradacji. Eliptyczność, kontrapunktowość, zwłaszcza stopień ogólności czyni banalny wiersz uniwersalnym. Dlaczego sześć, czego symbolem może być ta liczba? Sześć daremnych prób odejścia, jeśli drzewo podróżnika (ravenala) ma symbolizować - jak na ogół palma w malgaskiej topice - mężczyznę: tego, który odszedł, i który żałuje? Próbuje zawrócić, naprawić błąd, na różne sposoby? Podobno liczby 3 i 6 oznaczają u Malgaszy pełnię: podmiot wiersza Ranaivo wyczerpał więc wszystkie możliwości, aż pojął, że nie ma wyjścia z sytuacji... prócz najtrudniejszego, niepewnego.

Łatwiej zinterpretować wiersz Rabearivelo Les trois oiseaux [Trzy ptaki] ze zbioru Presque-Songes [Niemal-sny] (wyd. fr. 1934), który wraz z tomikiem Traduit de la nuit [Przekład z nocy] (wyd. fr. 1935) ukazuje tzw. drugą manierę w twórczości ojca malgaskiej literatury francuskojęzycznej, zmarłego śmiercią samobójczą, która nadbudowała legendę nad jego dziełem, i tak niezwykłym. Od debiutu wiosną 1921 roku (wiersz Le Couchant

\footnotetext{
35 Ale to Senghor wspomina o Malgaszach w nocie wydawcy [s. 2], zaznaczając, że nie uważają się za Murzynów, lecz Melanezyjczyków, jak Rabearivelo, który się przedstawiał jako „melanien”; stąd i tytuł antologii „poezji murzyńskiej i malgaskiej”. Sartre pisze o Martynikańczyku Aimé Césaire (1913-2008), twórcy pojęcia négritude, wespół z L.S. Senghorem i L. Damasem.
} 
w „La Tribune de Madagascar”), przez pierwszy artykuł o malgaskiej poezji w austriackim "Anthroposie" z 1923 roku, poeta stara się naśladować symbolistów, których też tłumaczy, wedle przyjętej zasady: pisać po francusku na malgaską modłę („écrire en français sur des modes malgaches"), czerpiąc z malgaskiego imaginarium ${ }^{36}$. Druga maniera polegała na pisaniu jednoczesnym, naprzemiennym (po malgasku i po francusku) od roku 1931 obu serii, które, błądząc na granicy snu i jawy, między idiomami dwóch cywilizacji, śladem Baudelaire'a próbują odnaleźć pierwotny język poezji i ziścić marzenie Mallarmé'go o zapomnianym, czysto poetyckim pra-języku, języku absolutnym ${ }^{37}$.

L'oiseau de fer, l'oiseau d'acier, après avoir lacéré les nuages du matin et voulu picorer des étoiles au-delà du jour, descend comme à regret dans une grotte artificielle.

L'oiseau de chair, l'oiseau de plumes qui creuse un tunnel dans le vent pour parvenir jusqu'à la lune qu'il a vu en rêve dans les branches, tombe en même temps que le soir dans un dédale de feuillage.

Celui qui est immatériel, lui, charme le gardien du crâne avec son chant balbutiant, puis ouvre des ailes résonnantes et va pacifier l'espace pour n'en revenir qu'une fois éternel.
Ptak żelazny, ptak stalowy, Postrzępiwszy poranne chmury chciał zdziobać gwiazdy ponad horyzontem, schodzi z żalem do sztucznej groty.

Ptak cielesny, ptak pierzasty, drążący tunel skroś wiatru by dosięgnąć księżyca widzianego we śnie wśród gałęzi zapada z wieczora w labirynt liści.

Ten niematerialny zaś czaruje strażnika czaszki swym bełkotliwym śpiewem, potem rozpościera dźwięczne skrzydła i ucisza przestrzeń, by powrócić z niej uwiecznionym.

Symbolika liczb wiąże się z symboliką atrybutów: „ptak z żelaza, ptak ze stali" (w. 1) - geniusz cywilizacji? "Ptak z ciała, ptak z piór" (w. 7) - żywioł natury? I wreszcie ten trzeci, ptak „niematerialny” (w. 13) i „wiecz-

\footnotetext{
36 Poeta zbierał i tłumaczył hainteny: z tych Vieilles chansons des pays d'Imérina (1939), sześć weszło w 1948 r. do antologii L.S. Senghora (s. 190-191). „Du hain teny, Rabearivelo retient le principe de la variation, jouant sur les retournements, rebondissements, étagements et superpositions du sens" [J.-L. Joubert, Littératures de l'océan Indien, Paris 1991, s. 67].

37 C. Riffard, Écrire en deux langues: l'expérience de Jean-Joseph Rabearivelo et d'Esther Nirina, „Études Littéraires Africaines. Madagascar” 2007, nr 23, s. 35-43.
} 
ny" (w. 18) - misterium sztuki? Sen o wieczności - Rabearivelo poświęcił mu swoją trzecią manierę, uwidaczniającą się w tzw. Galets [Kamyki] ${ }^{38}$. Tworzą zbiór najprostszych, z pozoru banalnych wierszy, zainspirowanych poezją, która, w przeciwieństwie do hainteny, pozostała dla niego "ciemna”, bo metafizyczna - wierszami Gongory i Rilke'go: „poszukiwanie Poezji nagiej i czystej" go zaprząta, jak notuje $\mathrm{w}$ dzienniku ${ }^{39}$. W cierpieniu i podczas rekonwalescencji powstaje wiosną 1933 roku zrąb 13 wierszy, dopełniony późniejszymi czterema: miały być "sekretne i umykające widziane oczyma dziecka - albo człowieka z wolna przywracanego do życia po długotrwałym lęku i nienazwanych cierpieniach"; na wzór kamyka na dnie strumienia, „,bez określonej formy", „,bez kantów”, ,proste i gładkie”; wiersz wolny przewodzi w nich radości pisania ${ }^{40}$.

Tradycyjna poezja malgaska posłużyła uwolnieniu francuskiego wiersza już w poprzednich zbiorach Rabearivelo, jakoby „przełożonych z języka hova [malgaskiego] przez autora" - podtytuł Presque-Songes z 1934 roku - który rok później wyznał w P.S. listu do Roberta Boudry (zaprzeczając wyznaniu sprzed roku, że jedynie "transkrybował" na francuski inedita pomyślane i zanotowane w hova):

Czas, bym wyznał Panu pewien... sekret; żadna z moich ksiażek nie została napisana w hova, wszystkie napisatem po francusku.

Lecz cóż: te spośród nich, które nie przyjmują formy tradycyjnej [...], te przedstawiam jako przełożone $\mathrm{z}$ hova. [...] Wszystko jest wtedy spisane poza Zachodem i z dala od niego.

Co do reszty, dzięki rytmowi i liczbie [sylab?], przedstawiam je jako Poezję francuską ${ }^{41}$.

Oto rola „pasera języka”, który stara się „pisać na sposób malgaski po francusku" („,écrire malgache en français"), dążąc do transkrypcji (transcription) lub transpozycji (transposition) zamiast przekładu (traduction), który jest

38 Ineditum, jak i malgaski tekst dwóch zbiorów z drugiej maniery (pierwodruk tychże: Hatier, Paris 1987, ze wstępem i pod red. J.-L. Jouberta, Les trois oiseaux, s. 27); Galets dopiero w 2012 r. miały swą premierę, w tomie 2 Dzieł wszystkich poety (tom 1 zawiera dzienniki i niektóre osobiste inedita).

39 J.-J. Rabearivelo, Calepins Bleus, 15/3/1933, w: tegoż, Euvres complètes, t. 1, Paris 2010, s. 89.

40 C. Riffard, [notice sur] Galets, w: J.-J. Rabearivelo, CEuvres complètes, t. 2, Paris 2013, s. 705-707.

41 C. Riffard, Sari-Nofy / Presque-Songes ou la quête du Chant, w: J.-J. Rabearivelo, CEuvres complètes, t. 2, s. 505-507. Jean-Louis Joubert zaświadcza o śladach przeróbek w zeszytach, gdzie obie wersje widnieją na sąsiednich stronach: "Comme si Rabearivelo n'écrivait plus directement ni en français, ni en malgache, mais dans le passage perpétuel d'une langue à l'autre" [J.-L. Joubert, Littératures de l'océan Indien, s. 67]. 
tylko niewierną i powierzchowną fotografią, gdy tymczasem wiersz przypomina film, a poeta - kompozytora, tworzącego do niego stosowny pod$\mathrm{kład}^{42}$. O Traduit de la nuit Jean-Louis Joubert pisze, że jest „inscenizacją przekładu" jako czegoś niemożliwego: bo jak tu jasno przedstawić gęstość nocy ("transcrire clairement l'opacité de la nuit")? ${ }^{43}$

W Les Dimanches de la vie (1952) Raymond Queneau (1903-1976) wyśmiewa stereotypy na temat Madagaskaru: weteran Walentyn Brû, nietęgi zabijaka, z grozą wspomina walki z okrutnymi hainteny merina:

- Alors, il paraît, comme ça, que vous fîtes campagne à Madagascar ?

- Oui. Contre les Hain-Tenys Merinas.

- C'était dur, hein?

- Comme ça.

- Et ça doit être beau, Madagascar.

- Pas mal. Plutôt montagneux.

- Et les indigènes?

- Ça, pour y en avoir, y en a.

- Ah ! les voyages, c'est beau, les voyages, et instructif ${ }^{44}$.

Pomimo powyższych przejawów Bakoly Domenichini-Ramiaramanana uważa, i chyba nie bez racji, że historia francuskiej recepcji hainteny to historia długiego zapoznania. Mogło przyczynić się do tego, jak sądzę, nieczyste sumienie metropolii po krwawym stłumieniu powstania w 1947 roku. Wcześniej zresztą wielu krytyków (Jacques Borel, Guy Dumur) podejrzewało Paulhana, że sam wymyślił ten gatunek. Jeśli o jakąśs „inwencję" może tu chodzić, zauważa Jean-Louis Joubert, długoletni wykładowca na wyspie, to raczej w sensie "odkrycia”, „znaleziska”: trafienia na niesłychany skarb literacki ${ }^{45}$. Madagaskar - wyspa literackich skarbów?

42 J.-J. Rabearivelo, D'un jeu plaisant mais périlleux, "Capricorne"1933, nr 3. Cyt. za: J.-L. Joubert, Littératures de l'océan Indien, s. 66.

43 „À défaut de dire en français toute la profondeur de la source poétique malgache, le texte poétique mime sa fonction de passeur d'un rivage culturel à l'autre. D'où la multiplication des effets de traduction. Transcriptions laissant affleurer quelques fragments malgaches à la surface du français (dans le poème 6, «Un oiseau sans couleur et sans nom/ a replié les ailes/et blessé le seul œil», il faut reconnaître derrière la belle métaphore une traduction-jeu de mot du malgache «masoandro», qui signifie "soleil», mais littéralement «œil du jour»). Transposition en français de procédures poétiques chères à la poésie traditionnelle (l'énigme sert de ressort à la plupart des poèmes du recueil)" [J.-L. Joubert, Poésie et traduction à Madagascar].

${ }^{44}$ Cyt. za: J.-L. Joubert, Poésie et traduction à Madagascar (motto jego artykułu). Powieść R. Queneau po polsku dostępna jest od niedawna: Niedziela życia, przeł. H. Igalson-Tygielska, Wrocław 2016.

45 J.-L. Joubert w Poésie et traduction à Madagascar powołuje się na artykuł B. Domenichini-Ramiaramanana, Lettre ouverte sur la littérature malgache, „Aujourd'hui l'Afrique” 1978, nr 11-12. 
Paulhan do tego stopnia przejął się swym odkryciem, że nawet w liście do stryjenki, Suzanne Paulhan, naśladuje styl hainteny (czy trafnie?):

Na ulicy, widząc mnie, wieśniak gwałtownie uchyla kapelusza.

Pozdrawia mnie, czy prosi o dwa grosze?

Jeśli go pozdrowię, a jemu chodzi o dwa grosze, ośmieszę się.

Lecz jeśli mu dam dwa grosze a on chciał mi jedynie okazać sympatię, zachowam się wstrętnie ${ }^{46}$.

„Jean Paulhan nie tyle wymyślił Madagaskar, ile raczej siebie wymyślił na Madagaskarze", niuansuje jego znajomy Roger Judrin ${ }^{47}$. Odnalazł sens pracy w pisaniu, przekładach, analizie, słowem przemógł "cień ojca” psychiatry, który zdominował syna w młodości, odnalazł własne życiowe powołanie. Madagaskar pomógł mu zobaczyć siebie - w opozycji do kolonialnej rzeczywistości, w dążeniu do niemożliwej symbiozy z malgaskim żywiołem. Kosztowało go to odkrycie wiele trudu, ale i zapewne (niełatwej) satysfakcji: codziennie spędza dwie i pół godziny nad przysłowiami ze starym Hova, i nawet podczas wakacji, rano i wieczorem, stara się nadrobić zaległości w ich wyjaśnianiu:

zostało mi jeszcze 1000. Nie wiem, czy jakiś inny vazaha [biały, cudzoziemiec] zna ich równie wiele. Do tego znalazłem starego Malgasza, który rozumie je prawie wszystkie, co najmniej 8 na 10, a to wiele ułatwia. $Z$ tym tylko, że jest bardzo stary i boję się, że umrze, jeśli pojadę sobie na wieśs ${ }^{4}$.

"L'EEdipe sans victoire d'un sphinx sans précipice”, jak żartobliwie pisze o swym koledze-łowcy zagadek Roger Judrin ${ }^{49}$. Dominique Ranaivoson oddaje mu hołd $\mathrm{w}$ autorskim Słowniku postaci historycznych zwiazanych $z$ Madagaskarem ${ }^{50}$. Paul Eluard (1895-1952) w Poésie involontaire et poésie intentionnelle (1942) rozwija koncepcję poezji, która przyjmuje równie dobrze słowo użyte nieświadomie, jak świadomie, pochodzenia ludowego, zrodzone z przypadku, jak i słowo dobrane intencjonalnie; poezję, w której gromadzą

\footnotetext{
46 Z listu do Suzanne Paulhan, 28 lipca 1903 (tj. 1908?), w: Cahiers Jean Paulhan - 2, s. 9 [tłum. - I.Z.]. To „ćwiczenie stylistyczne” zestawione jest $\mathrm{z}$ autentycznym hainteny, umieszczonym też jako motto poniżej.

47 R. Judrin, Introduction, w: Cahiers Jean Paulhan - 2. s. 11. Tom zawiera korespondencję z matką, ciotką, przyjaciółmi oraz niedokończoną rozprawę doktorską.

48 Cahiers Jean Paulhan - 2, s. 72.

49 Tamże, s. 11.

50 D. Ranaivoson, Madagascar. Dictionnaire des personnalités historiques, Saint-Maur/Madagascar 2005, s. 115-116.
} 
się nowe obrazy i kombinacje, gry powtórzeń i semantyczne echa, interteksty. A kto ją tworzy? „Tout homme est frère de Prométhée” ${ }^{51}$. Każdy jest poetą. Jak każdy Malgasz może tworzyć hainteny. O ile właściwie rozumie poezję, jako głębokie pojmowanie rzeczy świata tego.

\section{Bibliografia}

Cahiers Jean Paulhan - 2. Jean Paulhan et Madagascar 1908-1910 (1982), Paris: Gallimard. Domenichini-Ramiaramanana Bakoly (1968), Hainteny d'autrefois, Poèmes traditionnels malgaches recueillis au début du règne de Ranavalona 1 (1828-1861), Haintenin'ny fahiny, voaangona tamin'ny voalohandohan'ny nanjakandRanavalona I, Tananarive: Librairie Mixte.

Ferrand Gabriel (1913), Les Hain-tenys, "Journal Asiatique”.

Galibert Nivoelisoa, Palimpseste et itération dans l'écrit littéraire malgache de 1926 à 1972, brudnopis pliku autorskiego.

Gallieni Joseph Simon (1928), Lettres deMadagascar 1896-1905, Paris: Société d'Éditions géographiques, maritimes et coloniales, https://www.bibliothequemalgache. com/pdf/BME23.pdf.

Granet Marcel (1919), Fêtes et chansons anciennes de la Chine.

Hébert Jean-Claude (1964), Filan' Ampela, ou propos galants des Sakalava, „Journal de la Société des Africanistes", t. 34, fasc. 2, s. 227-254.

Joubert Jean-Louis (1991), Littératures de l'océan Indien, Paris: ÉDICELF/AUPELF.

Joubert Jean-Louis (1983), Poésie et traduction à Madagascar, „Étiopiques”, nr 34 i 35, revue socialiste de culture nǵro-africaine nouvelle série $3^{\mathrm{e}}$ et $4^{\mathrm{e}}$ trimestre de 1983, vol. 1, nr 3 et 4, http://ethiopiques.refer.sn/spip.php?article923.

Jousse Marcel (1925), Études de psychologie Linguistique, "Archives de Philosophie" II, IV.

Judrin Robert (1982), Jean Paulhan à Madagascar, d'une lettre à l'autre, w: Cahiers Jean Paulhan - 2. Jean Paulhan et Madagascar 1908-1910, Paris: Gallimard, s. 15-89.

Léry François (2001), Madagascar, les sortilèges de l'île Rouge, Paris: L'Harmattan.

Paulhan Jean (2007), Les Hain-teny merina: poésies populaires malgaches recueillies et traduites par [1913], Paris: Geuthner

Paulhan Jean (1938), Les Hain-teny, Paris: Gallimard [dodruk foto-offsetowy 1960].

Potocki Jan (1959), Podróże, oprac. L. Kukulski [przekład J.U. Niemcewicza poprawiony], Warszawa: Czytelnik, s. 320-321.

Rabearivelo Jean-Joseph (2010, 2012), CEuvres complètes, t. 1-2, Paris: Planète Libre/CNRS èditions/ITEM.

Ranaivoson Dominique (2005), Madagascar. Dictionnaire des personnalités historiques, Saint-Maur/Madagascar: Éditions Sépia, ÉditionsTsipika.

51 P. Éluard, Poésie involontaire et poésie intentionnelle [1942], w: CEuvres complètes, t. 1: 1913-1945, éd. M. Dumas, L. Scheler, Paris 1968, s. 1134. 
Riffard Claire (2007), Écrire en deux langues: l'expérience de Jean-Joseph Rabearivelo et d'Esther Nirina, „Études Littéraires Africaines. Madagascar", nr 23, s. 35-43.

Riffard Claire (2012), Sari-Nofy / Presque-Songes ou la quête du Chant, w: J.-J. Rabearivelo, CEuvres complètes, t. 2, Paris: Planète Libre/CNRS éditions/ITEM, s. $505-507$.

Senghor Léopold Sédar (2015), Anthologie de la nouvelle poésie nègre et malgache de langue française [1948], Paris: P.U.F.

Vigner Gérard (2015), L'École Jules-Ferry, école normale de l'enseignement colonial : une formation pour apprendre à enseigner dans les colonies (1902-1912), „Documents pour servir à l'histoire du français langue étrangère ou seconde", $\mathrm{nr}$ 5: (Se) former pour enseigner le français à ceux qui ne le parlent pas nativement, s. 57-82, https://journals.openedition.org/dhfles/4273.

\title{
Illustrious Destiny of an Obscure Poetry: Jean Paulhan - a Bard of Hainteny Merina
}

\begin{abstract}
The article concerns the works of Jean Paulhan, who promoted the genre of African poetry hainteny merina. In 1913, three years after Paulhan came back from Madagascar, where he had spent more than two years, one hundred and sixty popular hainteny merina (Malagasy) poems were published in Paris. It was the poetry of authority and struggle, named also the poetry of amorous dispute. Translated and explained, it would inspire in the interwar period and later on the Malagasy writers (Rabearivelo, Ranaivo) and the French ones (Éluard, Quéneau).
\end{abstract}

Keywords: popular poetry, hainteny merina, Madagascar, Jean-Joseph Rabearivelo, Flavien Ranaivo 